\title{
Cytotoxic Activity of Hyptis pectinata Extracts on MCF-7 Human Breast Cancer Cells
}

\author{
Nur Dina Amalina ${ }^{1}$, Meiny Suzery ${ }^{2 *}$, Bambang Cahyono $^{2}$ \\ ${ }^{1}$ Pharmacy Study Program, Chemistry Department, Faculty of Mathematics and Natural Sciences, \\ Semarang State University, Semarang, Indonesia \\ ${ }^{2}$ Chemistry Department, Faculty of Sciences and Mathematics, Diponegoro University, Semarang, Indonesia
}

\begin{abstract}
Hyptis pectinata (L.) poit, popularly known in the world as "comb bushmint" is a medicinal plant commonly used for the treatment of throat and skin inflammations, bacterial infection, pain and cancer. The objective of this research is to determine the cytotoxic and antiproliferative effect of Hyptis pectinata ethanolic extract (HPE) on breast cancer cells. The effect HPE on cytotoxicity was examined by 3-(4,5-dimethylthiazol-2-yl)-2,5-dphenyl tetrazolium bromide (MTT) assay on michigan cancer foundation (MCF-7) breast cancer cells. This assay also used to determine cell proliferation over 3 days of treatment with HPE concentration between 1.5-100 $\mu \mathrm{g} / \mathrm{mL}$. HPE showed that exhibited cytotoxic effects with $\mathrm{IC}_{50}$ value of $46 \mu \mathrm{g} / \mathrm{mL}$ for $24 \mathrm{~h}$ and changes the physiological morphology on MCF-7 cells. Interestingly, the treatment of HPE for 48 and $72 \mathrm{~h}$ highly decreases cell viability on MCF-7 with dose and time-dependent manner compared to untreated cells. These results indicate that HPE has antiproliferative activities and maybe the potential to be used in drug design in an attempt to develop new compounds with fewer side effects when compared to conventional chemotherapy.
\end{abstract}

Keywords: Hyptis pectinata (L.) poit extract, cytotoxicity, antiproliferative, MCF-7 cells

\section{INTRODUCTION}

Breast cancer is the most leading death cancer in the women. In 2018 new cases of cancer accounting 1.67 million and 0.5 million cancer-related death among women (Bray, et al., 2018). In Indonesia, have the same phenomenon, approximately $30.5 \%$ of all cancer diagnosed and $21.5 \%$ of cancer-related deaths (Krok-schoen, et al., 2016). Early diagnostic procedures and effective screening can prevent the severity of breast cancer. Unfortunately, breast cancer diagnosed at a late stage in many patients (migration stage), and there is no effective curative treatment (Huang, et al., 2017). In Indonesia, chemotherapy is one of the common treatments for breast cancer at all stages, but this treatment have many adverse side effects such as hepatotoxicity, cognitive dysfunctions, fatigue, and reduction in quality of life ratings (Kayl and Meyers, 2006). Hence, there is an urgent need to discover new anticancer drug leads.

Plant extracts and derived active principles have served as a major source for new pharmaceuticals for treatment of malignant

Submitted: October 24, 2019

Revised: December 9, 2019

Accepted: December 10, 2019

*Corresponding author: meiny_suzery@yahoo.com 
tumors. Hyptis pectinata (L.) poit has more than 400 species distributed in tropical climates such as Indonesia, 146 are endemic to brazil and popularly known as "sambacaita" (Porter, et al., 1995; Pålsson and Jaenson, 1999; De Almeida and De Albuquerque, 2002). Hyptis pectinata is a medicinal plant popularly used for anticancer, antioxidant, anti-inflammatory, antiociceptive, and antimicrobial (Miranda, et al., 1993; Santos, et al., 2008; Raymundo, et al., 2011; Santana, et al., 2019). Hyptis pectinata extract (HPE) is capable on inhibiting the growth of human colon carcinoma cell line (HCT-8) with moderate cytotoxic activity (Barbosa, etal., 2012). Based on the above data, there is no one information about the potential of HPE on human breast cancer cells. Hence, the objective of the present study was to analyze the cytotoxic and anti-proliferative activity of HPE on human breast cancer michigan cancer foundation (MCF-7) cells.

\section{METHODS}

\section{Plant Material}

Hyptis pectinata (L.) poit (plant genus: Hyptis, plant family: Labiate) (Steenis, 1992) was collected in Kanayakan village, Bandung West Java, Indonesia. Voucher specimen (MS 100562) was deposited at the herbarium Biology, Faculty Sains and Mathematic, Diponegoro University, Semarang, Indonesia. The leaves of Hyptis pectinata, were dried at $45^{\circ} \mathrm{C}$ and mashed into powder. Dried powdered leaves was extracted by maceration with ethanol at room temperature. After filtration, the solvent was evaporated under reduce pressure in a rotary vacuum evaporator to result the crude extracts of the plant (Achmad, et al., 1987; Suzery, et al., 2012).

\section{Cell Culture}

MCF-7 was obtained from the American Type Culture Collection (ATTC ${ }^{\circledR}$ HTB-22TM) (Manassas, Virginia, USA). The cell culture methods was adapted from (Khamsita, et al., 2012) with slightly modification. Briefly, MCF-
7 cells was cultured in Dulbecco's Modified Eagle's Medium (DMEM) (Gibco, New York, USA) supplemented with $10 \%(\mathrm{v} / \mathrm{v})$ fetal bovine serum (FBS) (Gibco), $150 \mathrm{IU} / \mathrm{mL}$ penicillin, 150 $\mu \mathrm{g} / \mathrm{mL}$ Streptomycin (Gibco) and 12,5 $\mu \mathrm{g} / \mathrm{mL}$ Amphotericin B (Gibco). Cells were grown at $37^{\circ} \mathrm{C}$ with $5 \% \mathrm{CO}_{2}$ in a humidified atmosphere.

\section{Cytotoxic Assay}

The cytotoxicity of HPE was tested using 3-(4,5-dimethylthiazol-2-yl)-2,5-dphenyl tetrazolium bromide (MTT) assay according to (Mosmann, 1983) with slight modifications. MCF7 cells $\left(2 \times 10^{4}\right)$ were seeded in 96-well microplate and divided into an untreated and treated groups. After $24 \mathrm{~h}$ of incubation, the medium replaced with a series of concentrations of HPE. Cells were treated with HPE $(1.562 ; 3.125 ; 6.25 ; 12.5 ; 25 ; 50$; and $100 \mu \mathrm{g} / \mathrm{mL})$. Untreated cells were regarded as negative controls. After $24 \mathrm{~h}$ of treatment, the medium was discarded and replaced with $0.5 \mathrm{mg} /$ $\mathrm{mL}$ of MTT (Biovision, California, USA) and incubated for approximately four hours at $37^{\circ} \mathrm{C}, 5 \%$ $\mathrm{CO}_{2}$. Cells were lysed using 10\% sodium dodecyl sulfate (SDS) stopper containing $0.01 \mathrm{NHCl}$ and incubated in the dark condition overnight to dissolve formazan salt. After incubation, the absorbance was measured by Enzyme-linked Immunosorbent Assay (ELISA) reader plate at $\lambda 550 \mathrm{~nm}$. The absorbance was converted to \% cell viability by comparing the treated group with the untreated at a particular time course. Linear regression between concentration $(\mathrm{x})$ and $\%$ cell viability $(\mathrm{y})$, giving the equation $\mathrm{y}=\mathrm{Bx}+\mathrm{A}$ were used to calculate $\mathrm{IC}_{50}$ value. Using the linier equation of this graph for $\mathrm{y}=50$ value $\mathrm{x}$ point becomes $\mathrm{IC}_{50}$ value, that is the concentration inhibiting $50 \%$ cell proliferation. The data of this study was carried out with 3 replication experiments.

\section{Proliferation Assay}

In the experiments to measure proliferation rates, $5 \times 10^{4}$ MCF-7 cells were seeded in 96-well microplate as described above and treated with HPE 
at several concentration $(1.562-100 \mu \mathrm{g} / \mathrm{mL})$ for 24 , 48 , and $72 \mathrm{~h}$ before MTT. The data of this study was carried out with 3 replication experiments.

\section{Statistical Analysis}

The data were expressed as the mean \pm standard error of the mean (SE) of 3 experiments. One-way analysis of variance followed by the least significant difference test was used for statistical analyses (Microsoft, Redmond, USA). P values less than 0.05 were considered statistically significant.

\section{RESULTS}

The objective of this research was to develop HPE as a novel natural chemotherapeutic agent for breast cancer. To determine the cytotoxic activity of HPE, MCF-7 breast cancer cells incubated in the presence $(1.562$ to $100 \mu \mathrm{g} / \mathrm{mL}$ ) of HPE in vitro for $24 \mathrm{~h}$. The cytotoxic activity was analyze under MTT assay, and the $\mathrm{IC}_{50}$ value presented the cytotoxic effect of HPE. The treatment with HPE for $24 \mathrm{~h}$ induced morphological changes (Figure 1). HPE at the middle concentration (25 $\mu \mathrm{g} / \mathrm{mL})$ induced cell shrinkage and high concentration $(100 \mu \mathrm{g} / \mathrm{mL})$ there was more number

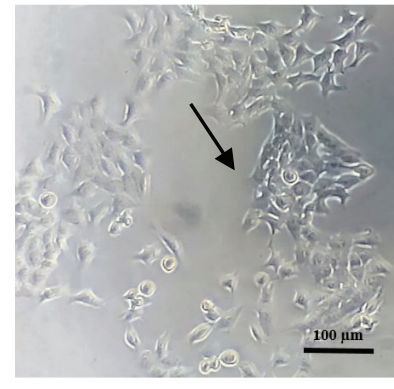

Untreated

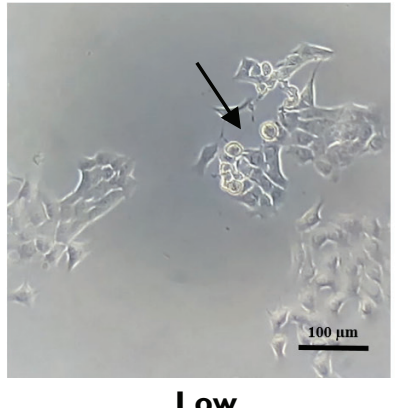

Concentration
Middle

Concentration

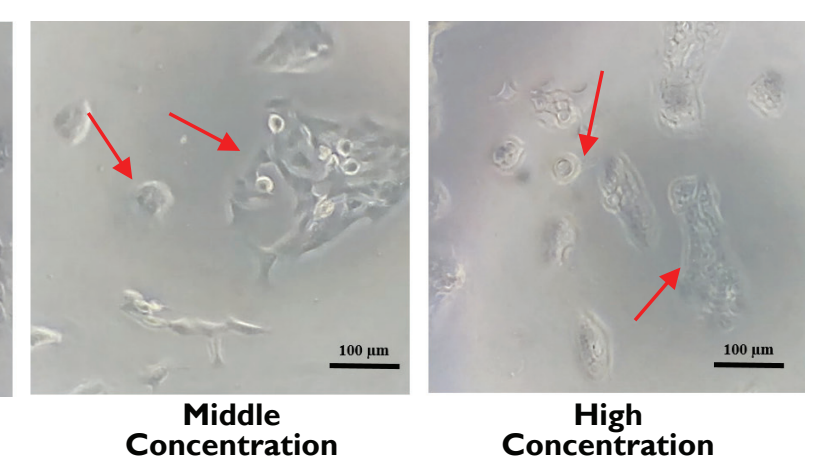

of cell shrinkage and fragmentation. However, the untreated and low concentration $(1.562 \mu \mathrm{g} / \mathrm{mL})$ did not show morphological changes. In addition, treatment of HPE for $24 \mathrm{~h}$ revealed cytotoxic effect on MCF-7 cells with $\mathrm{IC}_{50}$ value of $46 \mu \mathrm{g} /$ $\mathrm{mL}$ (Figure 2A). HPE higher than $12.5 \mu \mathrm{g} / \mathrm{mL}$ significantly suppressed the growth of MCF-7 cells compare with untreated cells as negative control. Following treatment of the MCF-7 cells with ethanolic extracts for $24 \mathrm{~h}$, the morphology of cells altered clearly especially at higher concentrations. The detached round cells which were floating in the medium with the wrinkled nucleolus, bubbled membrane as well as decries, were obliviously seen in the MCF-7 cells. Such morphological features, which are sign of cell death and were not seen in the untreated cells.

Based on the data, further investigating the effect of HPE on the anti-proliferative effect after 24,48 , and $72 \mathrm{~h}$ of HPE treatment. For this purpose, MCF-7 cells cultured in the presence of HPE at the various time of treatment. Figure 2B shows that, HPE highly suppressed cell proliferation with $\mathrm{IC}_{50}$ value $42 \mu \mathrm{g} / \mathrm{mL}, 30 \mu \mathrm{g} / \mathrm{mL}$, and $17 \mu \mathrm{g} / \mathrm{mL}$ for 24 , 48 and $72 \mathrm{~h}$ treatment, respectively. Therefore, we concluded that HPE exhibit strong cytotoxic activity in dose and time dependent manner on MCF-7 cells.

Figure 1. The effect of HPE on MCF-7 cell morphology. MCF-7 cells $\left(2 \times 10^{4}\right)$ were seeded in 96 well plate and incubate for $24 \mathrm{~h}$, then treated with HPE $(1.562-100 \mu \mathrm{g} / \mathrm{mL})$ for $24 \mathrm{~h}$. Obvious morphological changes and cell population in the treatment of HPE concentration of untreated, low concentration $(1.562 \mu \mathrm{g} / \mathrm{mL})$, middle concentration $(25 \mu \mathrm{g} / \mathrm{mL})$, and high concentration $(100 \mu \mathrm{g} / \mathrm{mL})$. Black arrows indicated normal living cells, whereas red arrows indicated the cell morphological changes. HPE at the middle concentration $(25 \mu \mathrm{g} / \mathrm{mL})$ induced cell shrinkage and high concentration $(100 \mu \mathrm{g} / \mathrm{mL})$ there was more number of cell shrinkage and fragmentation. Cell morphology observations conducted with an inverted microscope with a magnification of 100x. Scale bar: $100 \mu \mathrm{m}$. 

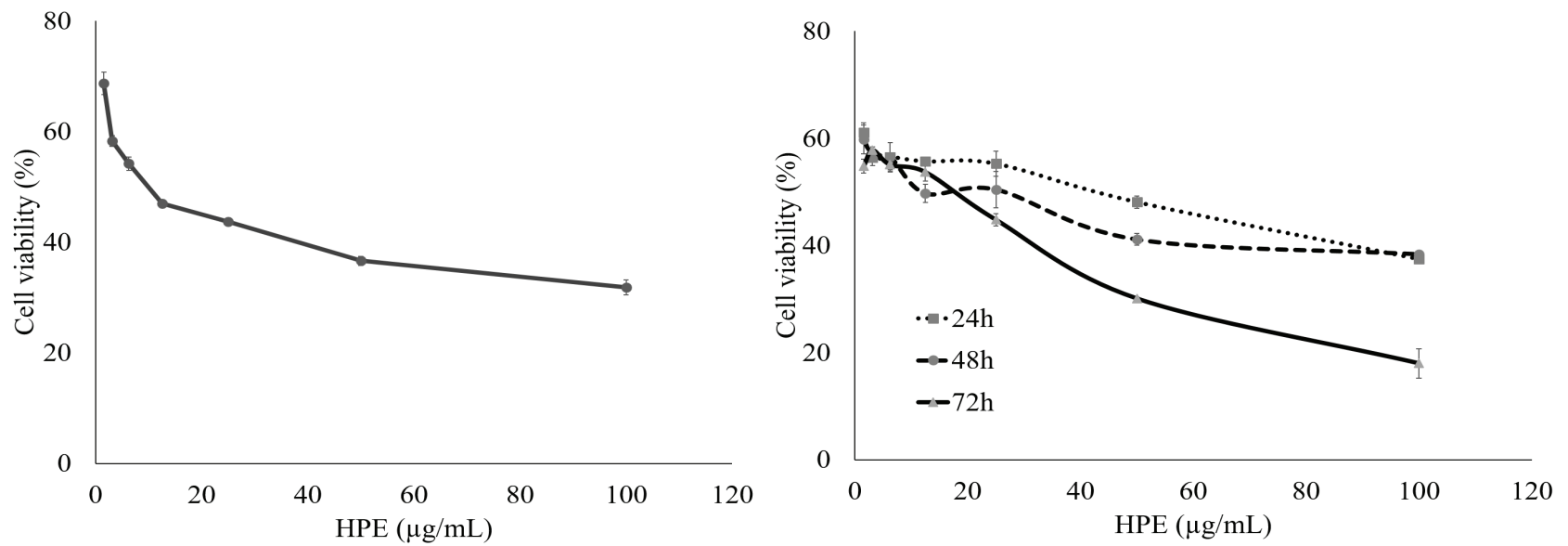

Figure 2. Effect of HPE on the cell viability of MCF-7 cells. (A) MCF-7 cells $\left(2 \times 10^{4}\right.$ cells $\left./ \mathrm{mL}\right)$ were culture in presence of HPE (1.562-100 $\mu \mathrm{g} / \mathrm{mL})$ for $24 \mathrm{~h}$, HPE performed cytotoxic effect with $\mathrm{IC}_{50}$ value of $46 \mu \mathrm{g} / \mathrm{mL}$. (B) MCF-7 cells $\left(2 \times 10^{4}\right.$ cells $\left./ \mathrm{mL}\right)$ in 96-well plates for $24 \mathrm{~h}$ to adapt, then treated with HPE concentrations of 1.5625-100 $\mu \mathrm{g} / \mathrm{mL}$, then incubated again for $24 \mathrm{~h}, 48 \mathrm{~h}$, and $72 \mathrm{~h}$. Profiles of cell viability expressed mean \pm SD of 3 experiments. $I C_{50}$ obtained from the linear regression calculation of cell viability vs log concentrations with $p<0.05$.

\section{DISCUSSION}

Nowdays, it is important to explore new source of natural medicines because the demand for such drugs is increasing. Plants are rich source of anticancer agents and many of the anticancer drug in the market are derived from them (Lampronti, et al., 2006; Newman and Cragg, 2007; Pan, et al., 2010). In the past few years, a number of herbal medicines with potent anti-cancer activity were reported, such as Hyptis pectinata (Santana, et al., 2019). Previous study revealed that HPE could suppress human colon carcinoma HCT-8 cells with moderate cytotoxic activity (Barbosa, et al., 2012). Previous research also reported that pectinolide (one of the isolate compound from Hyptis pectinata (L.) poit) has a cytotoxic effect on triple-negative human breast cancer MDA MB 231 cells, and pectinolide often has significant cytotoxic activity against the colon, fibro sarcoma, and lung cells with $\mathrm{IC}_{50}$ value of $<4 \mu \mathrm{g} / \mathrm{mL}$ (Miranda, et al., 1993; Santana, et al., 2019). Inhibition of cancer growth has been a continuous effort in cancer treatment. Reducing cell growth are a major way of inhibiting cancer growth (Huang, et al., 2003). In this study, cytotoxic activity of HPE was observed on human breast cancer cells with several time of treatment.

In order to evaluate whether HPE could exert an anti-cancer effect on breast cancer, breast cancer cell lines were used, such as MCF-7 estrogen receptor positive $(\mathrm{ER}+)$. The addition of HPE to MCF-7 increased the cell mortality in a doses-dependent manner for $24 \mathrm{~h}$ with $\mathrm{IC}_{50}$ value of $42 \mu \mathrm{g} /$ $\mathrm{mL}$. Interestingly, in this research found that the ethanolic extract of Hyptis pectinata to be more effective than the methanolic extract $\left(\mathrm{IC}_{50}\right.$ value of $185.63 \mu \mathrm{g} / \mathrm{mL}$ ) in inhibiting breast cancer MCF-7 cells (Suzery and Cahyono, 2014). This activity might be due to influence of ethanolic extract of Hyptis pectinata may modulate estrogen receptor activation and more importantly estrogen-dependent breast tumors (Popolo, et al., 2009). In another hand, hyptolide and pectinolide compounds as the major metabolites of HPE also affect cytotoxic activity (Miranda, et al., 1993; Asy, et al., 2019).

Thus, based on these results cell proliferation was observed in several time variation of HPE treatment, for 24,48 , and $72 \mathrm{~h}$. The ethanolic extract had an outstanding inhibitory effect on proliferation with $\mathrm{IC}_{50}$ value $42 \mu \mathrm{g} / \mathrm{mL}, 30 \mu \mathrm{g} / \mathrm{mL}$, and $17 \mu \mathrm{g} /$ 
$\mathrm{mL}$ for 24,48 and $72 \mathrm{~h}$ treatment, respectively. The low percentage of live cells observed in the treated cells show effective proliferation activity of the plant extract against the MCF-7 cells. For $72 \mathrm{~h}$, the concentration required to reduce the growth of the MCF-7 cells to $50 \%$ was $17 \mu \mathrm{g} / \mathrm{mL}$. This concentration is considered to be very low, as according to the American National Cancer Institute, a value of $30 \mu \mathrm{g} / \mathrm{mL}$ is the highest $\mathrm{IC}_{50}$ that is considered promising when searching for activity in the whole extract (Kuete, et al., 2013). According to the previous studies, HPE is a rich source of hyptolide. This compound is that the decrease in cell viability may be due to the influence of $\alpha$-tubulin inhibition caused by hyptolide treatment as a consequence of its cell proliferation (Meiny, et al., 2012; Asy, et al., 2019). Collectively, our results demonstrated that HPE has cytotoxic and anti-proliferative activity against human breast cancer cells, and maybe can be used in drug design in an attempt to develop new compounds with fewer side effects when compared to conventional chemotherapy. Further studies are necessary for mechanism of cell death characterization and in vivo evaluation to identify effective anticancer of HPE.

\section{CONCLUSION}

The HPE has potential inhibited cell growth of human breast cancer MCF-7 cells. Furthermore, Hyptis pectinata can be used in drug design in an attempt to develop new compounds with fewer side effects when compared to conventional chemotherapy.

\section{ACKNOWLEDGMENT}

This research was supported by Grants of Fundamental Research from the Ministry of Research, Technology and Higher Education of Indonesia.

\section{REFERENCES}

Achmad, S., Hoyer, T., Kjaer, A., Makmur, L. and Norrestam, R., 1987, Molecular and crystal structure of hyptolide, a naturally occuring a,B-unsaturated $\delta$-lactone, ChemInform., 19(8), 599-609.

Asy, M. and Suzery, M., 2019, In silico study: the anticancer potency og hyptolide and analogue compounds through mechanism of a -tubulin inhibition, Int J Pharm Bio., 2019, 243-248.

Barbosa, C. V., Aquino, P.G.V., Ribeiro-Júnior, K.A.L., Moura, F.B.P., Alexandre-Moreira, M.S., Sant'Ana, A.E.G., Ferreira, J.R.O., Moraes, M.O., Pessoa, C., Aguiar, J.S., Silva, T.G. and Araújo-Júnior, J.X., 2012, Cytotoxic and antitumor activities of Hyptis pectinata (Sambacaitá) extract, Pharmacologyonline., 3, 70-74.

Bray, F., Ferlay, J. and Soerjomataram, I., 2018, Global Cancer Statistics 2018 : GLOBOCAN Estimates of Incidence and Mortality Worldwide for 36 Cancers in 185 Countries, CA: a cancer J. for Clinicians, 68(6), 394-424.

De Almeida, C.D.F.C.B.R. and De Albuquerque, U.P., 2002, Check-list of the family Lamiaceae in Pernambuco, Brazil, Brazilian Arch. Biol. Technol., 45(3), 343-353.

Huang, C.Y., Ju, D.T., Chang, C.F., Muralidhar Reddy, P. and Velmurugan, B.K., 2017, A review on the effects of current chemotherapy drugs and natural agents in treating non-small cell lung cancer, Biomed., 7(4), 12-23.

Huang, S.T., Yang, R.C., Yang, L.J., Lee, P.N. and Pang, J.H.S., 2003, Phyllanthus urinaria triggers the apoptosis and $\mathrm{Bcl}-2$ down-regulation in Lewis lung carcinoma cells, Life Sci., 72(15), 1705-1716.

Kayl, A.E. and Meyers, C.A., 2006, Side-effects of chemotherapy and quality of life in ovarian and breast cancer patients., Curr. Opin. Colloid Interface Sci., 18(1), 24-28. 
Khamsita, R., Hermawan, A., Putri, D.D.P. and Meiyanto, E., 2012, Ethanolic Extract of Secang (Caesalpinia sappan L.) Wood Perdorms as Chemosensitizing Agent Through Apoptotic Induction on Breast Cancer MCF-7 Cells, Indones. J. Cancer Chemoprevention, 3(3), 444-449.

Krok-schoen, J.L., Oliveri, J.M., Paskett, E.D. and Krok-schoen, J.L., 2016, Cancer Care Delivery and women' s Health : The Role of Patient Navigation., Front. Oncology, 6, 1-10.

Kuete, V., Voukeng, I.K., Tsobou, R., Mbaveng, A.T., Wiench, B., Beng, V.P. and Efferth, T., 2013, Cytotoxicity of Elaoephorbia drupifera and other Cameroonian medicinal plants against drug sensitive and multidrug resistant cancer cells, BMC Complement. Altern. Med., 13(1), 250-258.

Lampronti, I., Khan, M.T.H., Bianchi, N., Lambertini, E., Piva, R., Borgatti, M. and Gambari, R., 2006, Plants with antitumor properties: from biologically active molecules to drugs, Adv. Phytomedicine, 2, 45-63.

Miranda, R.P., Hernadez, L., Villavicencio, M.J., Novelo, M. and Ibarra, P., 1993, Structure and stereochemistry of pectinolides A-C novel antimicrobial and cytotoxic 5,6-dihydro-a-pyrones from hyptis pectinata, J Nat Prod., 56(4), 58393.

Mosmann, T., 1983, Rapid colorimetric assay for cellular growth and survival: Application to proliferation and cytotoxicity assays, J. Immunol. Methods, 65(1-2), 55-63.

Newman, D.J. and Cragg, G.M., 2007, Natural products as sources of new drugs over the last 25 years, J. Nat. Prod., 70(3), 461-477.

Pålsson, K. and Jaenson, T.G.T., 1999, Plant products used as mosquito repellents in Guinea Bissau, West Africa, Acta Trop., 72(1), 39-52.

Pan, L., Chai, H. and Kinghorn, A.D., 2010, The continuing search for antitumor agents from higher plants, Phytochem. Lett., 3(1), 1-8.

Popolo, A., Piccinelli, L.A., Morello, S., Cuesta-Rubio, O., Sorrentino, R., Rastrelli, L. and Pinto, A., 2009, Antiproliferative activity of brown cuban propolis extract on human breast cancer cells, Nat. Prod. Commun., 4(12), 1711-1716.

Porter, R.O.Y.B.R., Reese, P.B., Williams, L.A.D. and Williams, D.J., 1995, Acaricidal and Insecticidal Activties of Cadina-4, 10 (15)-Dien-3-One, Phytochemistry., 40(3), 735-738.

Raymundo, L.J.R.P., Guilhon, C.C., Alviano, D.S., Eline, M., Antoniolli, A.R., Cavalcanti, S.C.H., Alves, P.B., Alviano, C.S. and Fernandes, P.D., 2011, Characterisation of the anti-inflammatory and antinociceptive activities of the Hyptis pectinata ( L .) Poit essential oil, J. Ethnopharmacol., 134(3), 725-732.

Santana, F.R., Luna-dulcey, L., Antunes, V.U., Claudio, F., Cominetti, M.R., Duarte, M.C. and Silva, J.A., 2019, Evaluation of the cytotoxicity on breast cancer cell of extracts and compounds isolated from Hyptis pectinata ( L .) poit, Nat. Prod. Res., 0, 1-8.

Santos, P.O., Costa, M.D.J.C., Alves, J.A.B., Nascimento, P.F.C., De Melo, D.L.M., Barbosa, A.M., Trindade, R.D.C., Blank, A.F., Arrigoni-Blank, M.F., Alves, P.B. and Do Nascimento, M.D.P.F., 2008, Chemical composition and antimicrobial activity of the essential oil of Hyptis pectinata (L.) Poit, Quim. Nova., 31(7), 1648-1652.

Suzery, M., Kusniawati, E., Hudiyanti, D. and Cahyono, B., 2012, Sintesis senyawa $\mathrm{C} 18 \mathrm{H} 2609$ dari Hiptolida Hasil Isolasi Daun Hyptis Pectinata, Reaktor, 14(1), 68-72.

Suzery, M. and Cahyono, B., 2014, Evaluation of Cytotoxicity Effect of Hyptis pectinata Poit ( Lamiaceae ) extracts using BSLT and MTT methods, Jurnal Sains dan Matematika, 22(3), 84-88. 